\title{
Characteristics of Redistributed Manufacturing Systems: A comparative study of emerging industry supply networks
}

\author{
Jagjit Singh Srai*, Tomas S. Harrington, Manoj K. Tiwari \\ *Corresponding author: e-mail jss46@cam.ac.uk, Centre for International Manufacturing, Institute \\ for Manufacturing, Department of Engineering, University of Cambridge CB3 OFS
}

\begin{abstract}
This paper explores the characteristics of redistributed manufacturing systems within the context of emerging industry supply networks (EI SNs), with a particular focus on their structure, operations and reconfiguration dynamics.

A number of factors have resulted in the redistribution of manufacturing. Within Emerging Industries, advances in process and information technologies, have changed the physical and information characteristics of components and products, and the viable production economies of scale. Further, the emergence of new specialised companies fulfilling key research, production or service roles have changed industry structure and operations, and the conventional model of value creation.

Six industrial systems are examined using an Industrial System mapping methodology (Srai 2016) providing a basis for cross-case analysis, selected on the basis of representing alternative and novel evolution paths that may provide insights in to the characteristics of EI SNs within a redistributed manufacturing context.

Cross-case analysis suggests several generic aspects to EI SNs, including the blurring of traditional industry boundaries and the critical requirement to manage uncertainty. Alternative forms of EI SNs are observed supporting particular El evolution paths. Further, more adaptive SNs support increased product variety, with lower inventory models enabled by enhanced production and distribution flexibility, often located closer to demand.
\end{abstract}

\section{Keywords}

Supply Chain Design, Supply Chain Management, Supply Chain Dynamics, Emerging Industry, Distributed Manufacturing

\section{Introduction}

Over recent decades, market dynamics have brought about the need for more flexible, reconfigurable and scalable organisational structures to support increasingly dispersed manufacturing resources (Shin et al, 2009; Harrington and Srai, 2012). In turn, supply networks have become increasingly 'disaggregated', with activities spread across multiple firms and locations, with individual manufacturing sites increasingly geographically distributed (Srai and Christodoulou, 2014, Srai et al 2016). More recently the concept of 'distributed manufacturing' has emerged, defined as 'the ability to personalize product manufacturing at multiple scales and locations, be it at the point of consumption, sale, or within production sites that exploit local resources, exemplified by enhanced user participation across product design, fabrication and supply, and typically enabled by digitalisation and new production technologies' (Srai et al 2016). Further the related concept of 'redistributed manufacturing' is where the transformation from a 'current state' to a 'future state', through new production and infrastructural technologies, involves a radical change in the geographical dispersion of production facilities, normally from a high volume centralised model to a lower volume dispersed factory model, located closer to the point of use. This paper explores the characteristics of such redistributed manufacturing systems within the particular context of emerging industry supply networks. Here, focus is centred on the implementation of emerging technological advancements within distributed manufacturing and the implications for both industry structure, SN operations and (re-) configuration dynamics. 
Recent research (e.g. Rezk et al 2016) has explored how supply network structure, in terms of upstream and downstream tier structure, and its geographic dispersion, is significantly influenced by the characteristics of the components and final products of these manufacturing SNs. The component and product characteristics we are concerned with are both physical (e.g. value density) and knowledge (e.g. the codification of information) and these act to constrain the available geographic dispersion options available to firms. Critically, the adoption of specific emerging technologies can fundamentally change these characteristics, thus requiring a re-assessment of the distributed nature of resulting manufacturing supply chains. In this way the redistribution of manufacturing can be significantly impacted by the development of these emerging industries and their future evolution (MacCarthy et al 2016).

As emerging industries develop with varying levels of dynamism and complexity (Nair and Boulton, 2008) an Industrial System mapping methodology previously reported (Srai and Christodoulou 2014, Srai 2016) provides the basis of representing alternative and novel evolution paths that may provide insights in to the characteristics of EI SNs within a redistributed manufacturing context. The approach captures those environmental features that are influenced by dynamic factors (such as market, product, production system, technology, policy and resources) and providing the platform for cross-case analysis involving a series of industrial systems selected as part of this study.

The paper is structured as follows: section 2 first summarises the key literature that may inform the critical characteristics of redistributed manufacturing systems within the context of emerging industry supply networks (EI SNs). Section 3 next describes the methodological approach to mapping a series of industrial systems and its role in guiding cross-case analysis. Section 4 presents a summary of the findings, including summary mapping outputs. Section 5 presents the discriminating features of the cases with respect to EI SNs in terms of supply configuration mapping, $\mathrm{SN}$ operations analysis and context-specific advantages. Finally, sections 6 and 7 discuss conclusions and directions for future research.

\section{Literature Review}

This section reviews the academic literature and summarises the characteristics that may be particularly relevant to redistributed manufacturing systems in the context of El SNs. This section therefore considers Redistributed Manufacturing from a systems perspective, the literature on Industrial Emergence, alternative Supply Network models and the Contextual factors that might influence adoption.

\subsection{Redistributed Manufacturing - a systems perspective}

Analysis of the structure of various industrial systems (Porter 1983, Dicken 2003), and the performance of 'clusters' (Porter 1998, 2000) has largely focused on mature industries. However, a series of industrial systems - often enabled by new, innovative manufacturing processes and driven by individual actors, new enterprises, and coalitions of more established firms (Harrington and Srai, 2016) are emerging which may provide valuable insights for structure, network dynamics and network reconfiguration for redistributed manufacturing systems. In addition, studies to-date have largely have focused on macro level structural changes (Karlsson 2003; Jacobides et al 2007). However, systems analysis studies suggest multiple lenses are required to explain complex interactions, examining wider constraints and 'hidden connections' (Capra 2002), including those between the different elements of the system. This research focuses on one key perspective, on how El supply networks address and respond to the opportunities and challenges of (re-)distributed manufacturing models (Srai et al 2016), adopting an industrial 'systems' approach. A key challenge in this research has, therefore, been to develop, test and refine tools, techniques and assessment frameworks that capture these macro and micro level interactions, using SN configuration mapping and operations analysis techniques, to better understand the inter-firm relationships between supply chain actors within these dynamic industrial systems. Drawing on recent research, the analytical techniques will be used to 
explore the drivers behind the geographical changes in production location that arise from distributed manufacturing systems, characterised by the ability to digitalise key elements of design, production and supply-demand management, the need for greater customisation (or even personalisation) of the final product or service, and enhanced designer/producer/end-user participation across the manufacturing value chain (Srai et al 2016).

\subsection{Industrial emergence}

Emerging industries have been described as those "newly formed or re-formed industries that have been created by technological innovation, shifts in relative cost relationships, emergence of new consumer needs, or other economic and sociological changes that elevate a new product or service to the level of a potentially viable business opportunity" (Porter, 1980, p.215). They are typically based around a disruptive innovation, that is driven by technology that either "enables something that was previously impossible or only a theoretical possibility" or "leads to some very different value proposition for products and services" (Technology Strategy Board Strategic Report, 2010). This latter definition may be interpreted to mean that an innovative change in the value chain of the product, leading to change in value proposition, is also then a key component of an El. Hence disruptive technology should have the potential to lead to a new value proposition and, thereby, disrupt existing markets industries.

Many studies (e.g. Funk, 2012; Jacobides 2005, Jacobides and Winter, 2005; Jacobides, 2008) have taken the form of retrospective analyses of specific industries from the perspective of representative actors. Another common approach is to classify industrial emergence into phases based on industrial innovation with such labels as "nurture", "growth", "maturity" etc (e.g. Utterback, 1994). Most chart this from a pre-product R\&D phase, through technology demonstration to volume production and finally end of life. Product life cycle in Els is typically short and characterised by uncertainty in demand and supply. Other studies (e.g. Harrington and Srai 2016) consider product life cycle concepts from the embryonic, or pre-product R\&D phase, through mass production and finally end of life. A key element of strategic market analysis is predicting at which phase of the maturity curve new products will fit and tailoring the product development process accordingly (Awa, 2010). Furthermore, it is argued these studies are largely conceptual and descriptive, providing limited content and substance on what the supply network features of evolution may be. This can make identification and classification very subjective and does not provide insights on the operational actions that firms need to consider, or those alternative 'options' that may deliver additional supply network benefits (Harrington and Srai, 2016).

Els typically have many of the following characteristics in common: strong technological uncertainty, strategic uncertainty, high initial costs but steep cost reduction, many embryonic companies and spin-offs, first time uninformed buyers, state intervention (in the form of legislation or subsidy). A further condition for an industry to be considered in a state of emergence is that either the number of technically differentiated solutions to address a market need is increasing, or one in which the number of independent, competing actors in the industry is also increasing, or both.

\subsection{Supply networks}

The increasing focus on Els with their inherent uncertainties is in some ways compounded by changes in the industrial landscape for mature sectors arising from the twin impacts of globalisation and the dissolution of vertically integrated value chains. The importance of the evolution of SNs as an enabling element of industrial development has been identified in many studies, linking SN structure and configuration to innovation capability, for example in terms of complexity (Choi and Krause, 2006), production dynamics (Kamath and Roy, 2007) and network configuration (Srai and Gregory, 2008).

The 'selection' of an appropriate SN for an El is expected to be one of the keys in determining success. Companies which are the most successful in the immature phase of emergence are those 
which are fastest to market, whether through being able to attract early stage funding, or by being differentiated in technology or mode of delivery. However, a lack of understanding of the entire value chain and its supporting $\mathrm{SN}$ will see these companies fail to exploit their potential as the industry matures (Simchi-Levi, 2010).

In response to changes in global industrial dynamics, new forms of SN have emerged to ameliorate the growing uncertainty in supply and demand (Srai and Gregory 2008). These network types include: Network Integrators; Mass Customisation models; and global scale Single Product clusters. These network types provide new testing grounds for the ability of SN configuration to be linked to industrial emergence (Srai, 2007). Examples identified include;

- production systems involving 'system integrators' that orchestrate the manufacture and coordination of production and logistics enabling 'fabless manufacturing'

- global production networks, involving global scale production systems often located in new centres of production and supply

- new routes to market, involving web-facilitated delivery models that enable increasingly customised delivery solutions providing more choice and flexibility

- servitization models involving integrated after-sales services to manufactured goods; these service packages far from being 'tagged on' extras often generate the dominant revenue stream or source of value capture

- novel business models that provide unique products or services.

In this research, existing $\mathrm{SN}$ configuration analysis tools are adapted and developed to an emerging industry context, in order to understand the impact of broader institutional, industrial and SN actors on industrial transition. The 'configuration approach' has been effectively used in the strategic management literature to review the alignment of strategy and resources. Within strategic operations management, SN configuration has been shown to influence operational capability (Srai and Gregory, 2008) and hence may provide a useful approach to understanding EI SN development. From their study across a range of diverse, mature industrial sectors, the means by which the configurations of these elements were linked to the relative performance of the firms involved was assessed and archetypes proposed. In the definitions of Srai and Gregory, SN configuration may be described by four constituent elements, namely the network structure (upstream and downstream); the relationships and governance between network partners; the means by which materials are processed and information flows between firms; and the way the product value structure is constructed along the value chain. This approach is used as a basis for this research, and is further developed for the El context in the methodology section.

\subsection{Contextual Factors}

Within this research, as part of capturing relevant contextual factors we will capture the type of innovation that is being generated by a particular industrial system, and location advantages that are being observed.

Firstly, in terms of the type of innovation context, with the research emphasis on novel SNs supporting emerging industries, a broader notion of innovation is adopted that includes Product, Process and Business Model innovations (Williamson \& Zeng 2009). Also consistent with this definition and the unit of analysis under study, innovations that are observed within the value chain from R\&D through to product supply \& service are considered as part of case selection (Gregory 2005).

Secondly, many industry studies have also confirmed specific institutional and country specific advantages. Early work considered developed country multinationals (Rugman 2006, Ramamurthi and Singh 2010) and more recently these observations have been confirmed from emerging country multinationals (Brennan and Bakir 2016) in addition to the particular advantages a multinational 
organisation may have within a particular industry context. Although these are not the primary focus of this research, they nevertheless provide necessary 'context' and are therefore relevant dimensions when assessing specific industry cases. For example, creative, defence and healthcare industries in the UK benefit from the scale of national investments in closely related public institutions and public procurement. Similar patterns have been reported by the European Cluster Observatory on Emerging Industries, with SME national clusters in Eco-Industries and Maritime sectors (Scandinavian countries), Telecoms (Netherlands) and personalised medicines (Ireland).

\section{Research Approach}

The methodology adopted in this study (Srai, 2016) aims to capture the critical attributes of an industrial system, namely, the context, resources, activities, processes, actors, and interdependencies that support the creation and delivery of products and services. In terms of context, the mapping approach incorporates institutional actors (including government bodies, regulators, research bodies, demonstrator facilities) and specialist industrial actors that do not normally form part of the supply network mapping agenda, such as diagnostic and service providers, sector specific finance and venture capitalists. In terms of activities and processes, the approach maps the physical movement of materials, and their chemical and physical transformation 'end-to-end' through the various production and unit operations. Finally actor mapping enables connections and interdependencies to be identified between supply chain actors by capturing value flows (transactions), and the flow of information and materials' (Srai 2016).

Due to the complexity of the interactions within an industrial system and the context rich nature of industrial emergence, the case-study method was chosen to capture the target data. EI SN case studies were selected based on different types of disruptive innovation exhibited. The following industrial systems were examined, each representing alternative transformations;

- Emergence of product-service models within Defence Aerospace (DA)

- The transition of a Maritime cluster (MC) into a niche high-specification product supply

- The early evolution of firms supporting sustainable Built-Environments (BE)

- Technology Platform development in the UK Industrial Biotechnology industry (IB)

- Product generation changes in global Photovoltaics (PV)

- New routes to market within e-Commerce driven Last Mile (LM) Logistics

The six cases includes a mix of industrial systems that demonstrate new markets, technology platforms, new routes to market, and new product/service delivery models. In some cases, where there were multiple product categories (e.g. IB) or co-existing product-generations (e.g. PV) within the chosen industrial system, at least one focal-firm from each product category/generation was used to capture the category-specific elements of industrial emergence.

Data collection to support the capture of the industrial ecosystem therefore involved capturing;

- Institutional Actors e.g. research establishments, government bodies, industry forums

- EI SN configuration; by mapping structure, material and information flows between principal $\mathrm{SN}$ actors, coordination and governance arrangements, and product value structures

- Other (non-SC) Industrial actors e.g. equipment providers, diagnostic and service providers

These mapping activities informed the creation of the industrial ecosystem maps to be used in subsequent analysis. Relevant focal Firm, Government and Country specific advantages were also captured to capture the context in which emergence was taking place.

In addition, a separate research strand involved capturing the evolution path of the focal firms within each EI SN. This required capturing past, present and discussing future SN configurations of the focal-firm identifying and categorising network configuration patterns, and evolution stages. These network evolution paths were identified by respondents from the focal firms against the configuration 
dimensions (Srai and Gregory 2008; Srai, 2016), systematically progressing through evolution stages identified in the literature.

The final stage of the research involved cross-case data presentation and synthesis involving cross-sector comparison and analysis.

\subsection{Development of Cross-Case Method for Comparative Analysis}

A key goal of the research was to apply a consistent method of analysis to enable subsequent crosscase comparison.

The mapping framework and five stage approach (2014, Srai 2016), as summarised in Figure 1, was used to conduct the analysis and involved the mapping of:

- Institutional players and secondary stakeholders

- Sector specialists and primary stakeholders

- Value chain actors and activities

- Supply network archetypes that form the supply chain

- Firms within the supply network archetypes

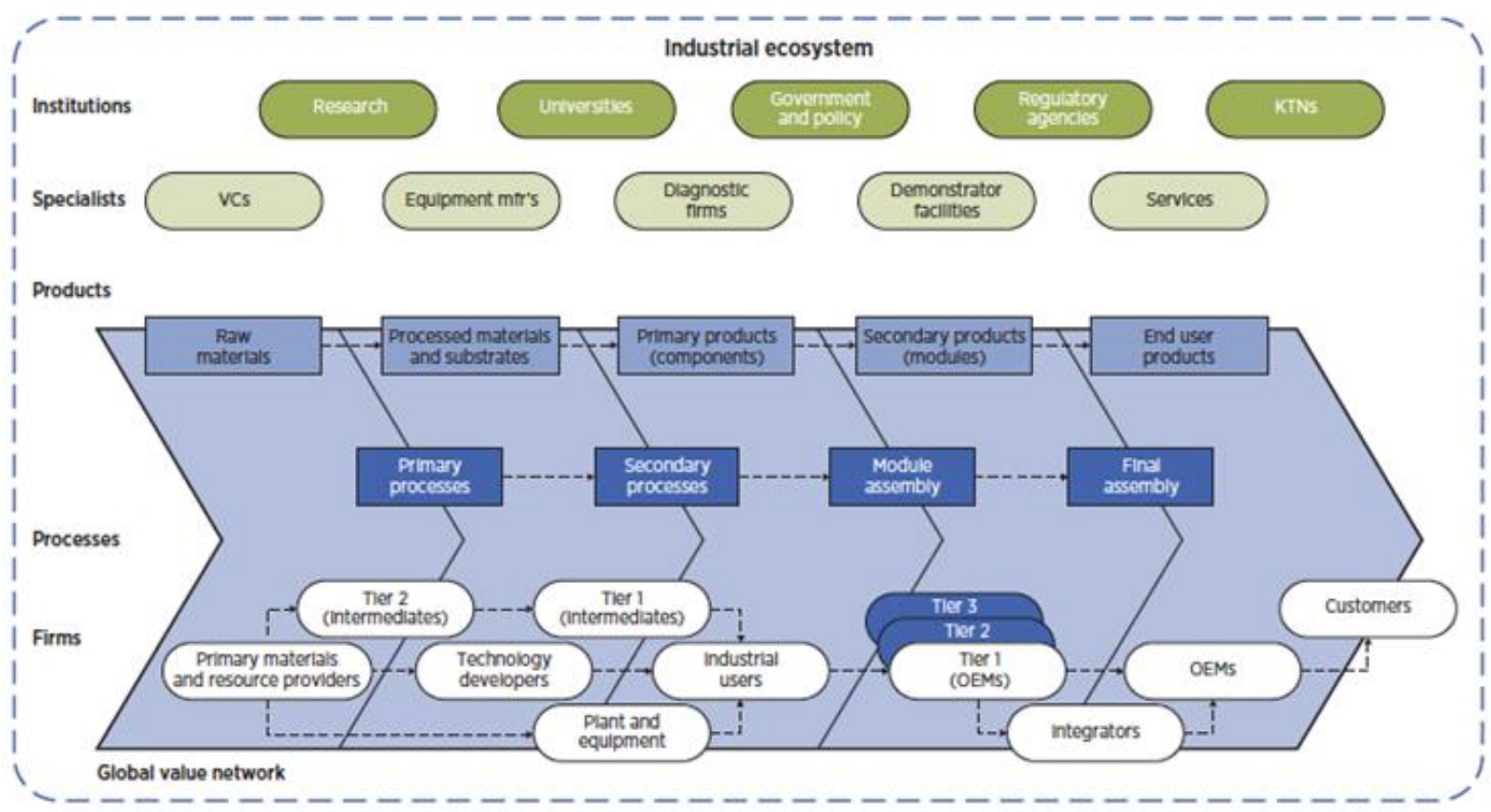

Figure 1. Generic Industrial Systems Mapping Framework (adapted from Srai and Christodoulou 2014, Srai 2016)

The industrial systems mapping framework was then used to capture the role of supply network actors in emerging industries, i.e.

- industry structure, at a broad industrial systems level

- alternative supply network configurations within the industrial system

- the identification of the evolutionary phases of the network within the industry enabling the generation of a stages model of emergence from the perspective of the supply network. 
Industrial system context and structure mapping involved focal firm case-study investigations with actors from each of the main product categories, with focal-firm case-selection based upon their central role in the value chain.

Respondents from focal-firms, informed the identification of various actors (Institutional, Industrial and SN) relevant to the industrial emergence dimensions presented to them. In addition they were requested to explore stages of $\mathrm{SN}$ evolution within the El systems, from a past or nascent product stage, through to their current stage of emergence, and consider potential future stages of industry maturity. These outputs, arising from these complementary methods, were used to generate an understanding of key enablers of emergence of each industrial system studied.

Beyond individual industrial system level analysis for the six industrial systems under review, using this standard methodology, cross-case analysis involved identifying generic patterns of emergence from a SN perspective. Generic cross-sector insights were then used to explore whether particular SN configurations had enabled or frustrated industry emergence.

\section{Industrial ecosystem mapping}

For each of the industrial systems studied, the first level of analysis involved the generation of an industrial ecosystem map across the manufacturing value chain using a common standard methodology, as described above, applied in a consistent manner, using a standard generic template (Srai and Christodoulou 2014, Srai 2016). As a representative sample of this industry mapping exercise, figures 2-7 set out the industry structure, principle supply chain actors and processes, for the six industrial systems studied. Appendix 1 Table 4 set out the nature of data collection including case study respondents interviewed, timelines involved in evaluating evolution paths, methods used for external peer-review, and data triangulation information sources. An overview of each industrial system is also presented in the following subsections.

\subsection{Defence aerospace service models}

To enhance productivity within this sector, as set out in Figure 2, characteristics linked to the redistribution of manufacturing maintenance and upgrade activities largely centre on the transition to deliver 'outcome-based contract management' and unique customised services, with service delivery located at the point of use. Specific activities being pursued in order to capture 'high value' include:

- New contracting and sub-contracting mechanisms and protocols e.g. engines, manpower, systems support, spare parts involving multiple partners

- Integrating Design and Build know-how with Maintenance and Repairs

- The ability to configure and reconfigure products, product combinations, and resources to provide military capability to achieve desired effects

- At an operational level, to achieve effective network integration across a more disparate set of industrial partners (lakovaki 2011, Srai 2011)

From an EI SN evolution perspective, 'Home markets' have been critical for historical sector evolution and ongoing intellectual property control, whilst adaptability (Network design and operation) vital to meet adjacent and new markets (products and regions).

\subsection{Maritime cluster}

Mapping of the maritime sector focused on the dynamic capabilities and the network relationships of a leading actor within the Norwegian maritime cluster, representing approximately $40 \%$ of the total turnover of Norwegian shipyards. The map (Figure 3) captures the interactions with vendors in particular, and the proactive role taken to manage the supply chain and increase the valueadd of network partners. The maritime cluster targeted is regarded as the leading innovative industrial 
district and production network within the offshore sector in Norway, with a dominant global position in the supply of high-value offshore maritime vessels (Guvåg et al, 2013). Specific characteristics linked to the redistribution of manufacturing within the sector include:

- Home market critical for cluster scale and consequent capability development, but geographical dispersion driven by the need to meet adjacent and new markets (products and regions)

- Design and equipment manufacturers, who traditionally enjoy high margin, communicating directly with ship owners as part of a disintermediation strategy,

- Assembly/shipyards, who traditionally face tight margins in Norway, partnering with overseas contractors for local build options for emerging market business

- Highly customised niche products requiring high levels of customisation

- High barrier to entry in ship manufacture limit dispersion options with in-house production providing capability to execute on novel design

- Direct customer interaction enabled through 'own production', with end-client conversations currently with ship-yards

Despite previous scale operations, there appeared no ongoing desire to compete in high volume commodity markets due to high local Norwegian labour costs and emerging competitors from SE Asia.

\subsection{Sustainable Built Environment}

Characteristics linked to the redistribution of manufacturing to enhance productivity within the emerging sector, as depicted in Figure 4, where retrofitting of existing buildings to provide energy efficiency, includes:

- Rapid commercialisation of new energy efficient technologies

- Retro-fit installation capability in highly urbanised environments

- Urban environment requires tailored delivery models e.g. consolidation centres, local government support, community engagement

- New concepts of value including carbon credits

- Significant role of institutional players including financial incentives and material disposal responsibilities

Within this emerging industrial system a number of alternative construction/retrofit models are being adopted depending on the nature of the build programme despite a common technology base. For new builds, contracting teams tend to have scale operations partnered with main largely private contracting organisations. Within locality based renovation projects, local institutional support was observed to be a key factor with significant responsibilities to re-use materials, whilst smaller scale retro-fitting projects involved smaller scale contracting operations with limited institutional oversight.

\subsection{Industrial Biotechnology}

This platform technology serves multiple end-user markets (Figure 5). Upstream R\&D, process technology and substrate developers introducing new product innovation with the ability to operate at lower scale than traditional chemical plants, thereby providing more options for distributed manufacturing models.

Downstream biochemical and industrial users of global scale - represent customer opportunities and also barriers (with sunk costs frustrating new capital investments). Alternative feedstocks, optimal growing conditions, and degradation dynamics determine new upstream locations, together with consideration of complex intermediate biochemical processing and storing options. 
Relatively benign operating conditions, low CAPEX, lower minimum economies of scale, higher volume flexibility enable more dispersed manufacturing opportunities. However, higher R\&D costs and more complex process control, including the need for close partnership between universities and demonstrator facilities. Further, the availability of finance, can at this early stage of technology development limit El development and geographical dispersion. This El has thus developed sector specialist venture capitalist industrial support actors that can provide funds for technology providers to evolve.

\subsection{Photovoltaics}

Utilising the photovoltaics case study, details of which are reported elsewhere (Kirkwood and Srai 2009), the mapping study enabled analysis of the ecosystem enablers for early maturity. The map illustrated in Figure 6 focuses on the transition between $1^{\text {st }}$ and $2^{\text {nd }}$ generation photovoltaic networks.

The study identifies the key ecosystem players that had an impact on enabling the shift to early maturity, and - most interestingly - the nature of their interventions. For example, this helped to answer questions such as: where are the sources of funding coming from, where is the R\&D being carried out, which policy groups are important, where are the demonstrator facilities for new technologies, and which critical service providers do they use (Srai and Christodoulou 2014, Kirkwood and Srai 2009).

This EI SN is particularly interesting, as rapid technology development and volatile energy pricing is driving erratic customer adoption of these emerging technologies; one can observe multiple technology generations or platforms co-existing and competing in the same market. Each of these technology generations/platforms are at different albeit early stages of maturity with uncertainty in technology compounded by uncertainty in market adoption and continuity of fiscal support.

\subsection{Last Mile Logistics}

Recent years have witnessed the development of new 'routes-to-market' involving specialist 'last-mile' consolidation and distribution service providers, coupled with the exponential rise of direct-toconsumer business delivery (Boyer et al, 2009, Aized et al 2013, Harrington et al, 2016).

In the context of this research, mapping of the last mile logistics urban system, focused on the dispersed nature of local to end consumer or customer pick-up or consolidation centres, linked to more flexible, dependable, resource efficient routes-to-market emerging. The case, Figure 7 reflects recent developments in the UK driven by consumer e-Commerce driven sales (Business to Consumer 'B2C', where the UK leads in this development in terms of percentage consumer sales) or concerns on urban congestion (Business to Business 'B2B') primarily due to construction. Characteristics emerging to enhance productivity included:

- Providing consumer choice; multiple options on delivery mechanism, time, location and format providing more local dispersed options

- Mass and late customisation enabled through customer-friendly information exchanges e.g. Apps, portals etc.

- E-commerce driven 'remote' sales and new IT-enabled sales channels that require can drive significant elasticity in demand and requires a similar flexible deliver capability

- Eliminating waste through consolidation (minimising missed deliveries, efficient forward/reverse logistics)

- Consolidation centres that enables value to be added at the local level (engaging new actors) whilst providing simplicity for remote suppliers and potential multi-modal connections. 
Figure 2. Defence aerospace service models

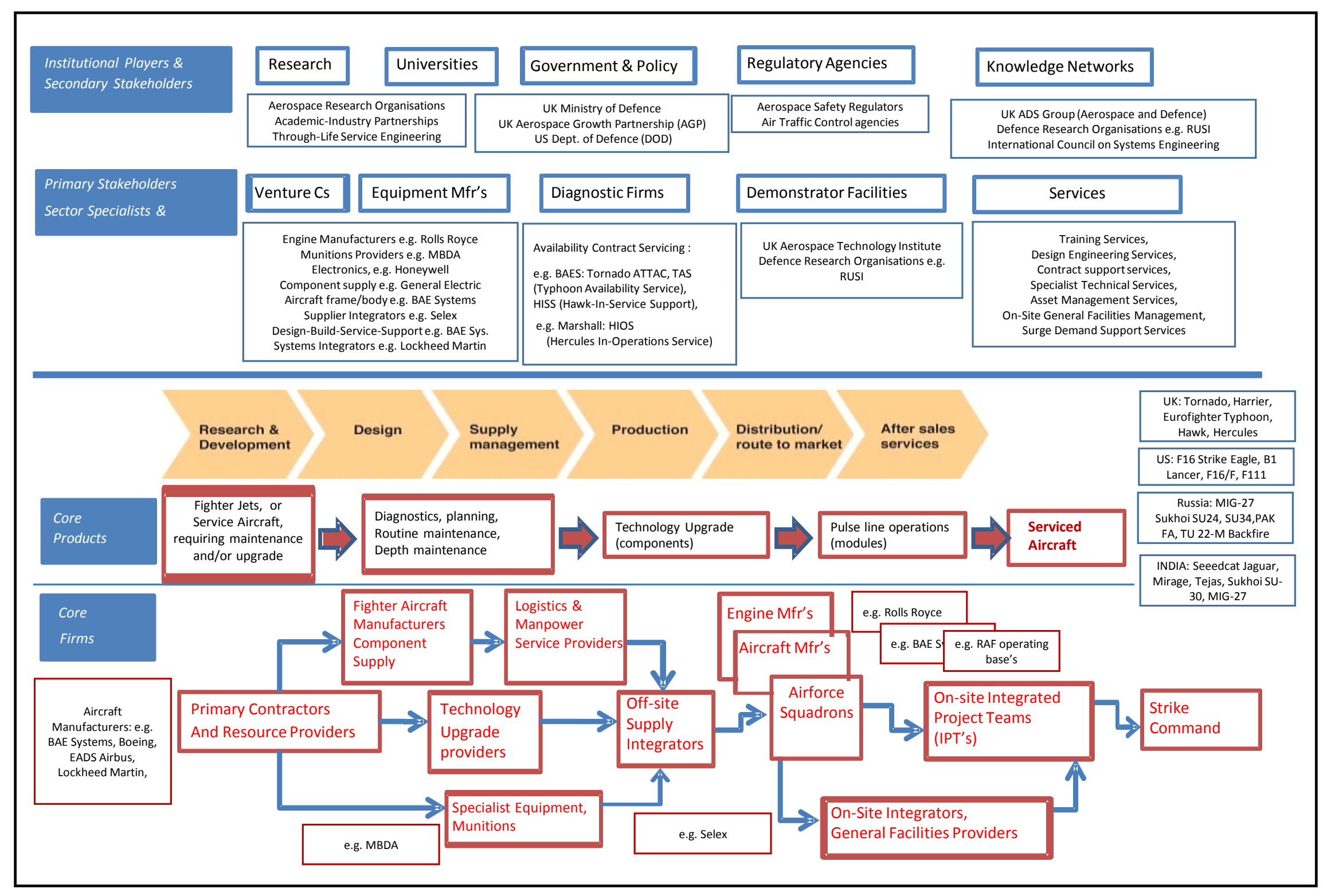


Figure 3. Maritime Cluster Map

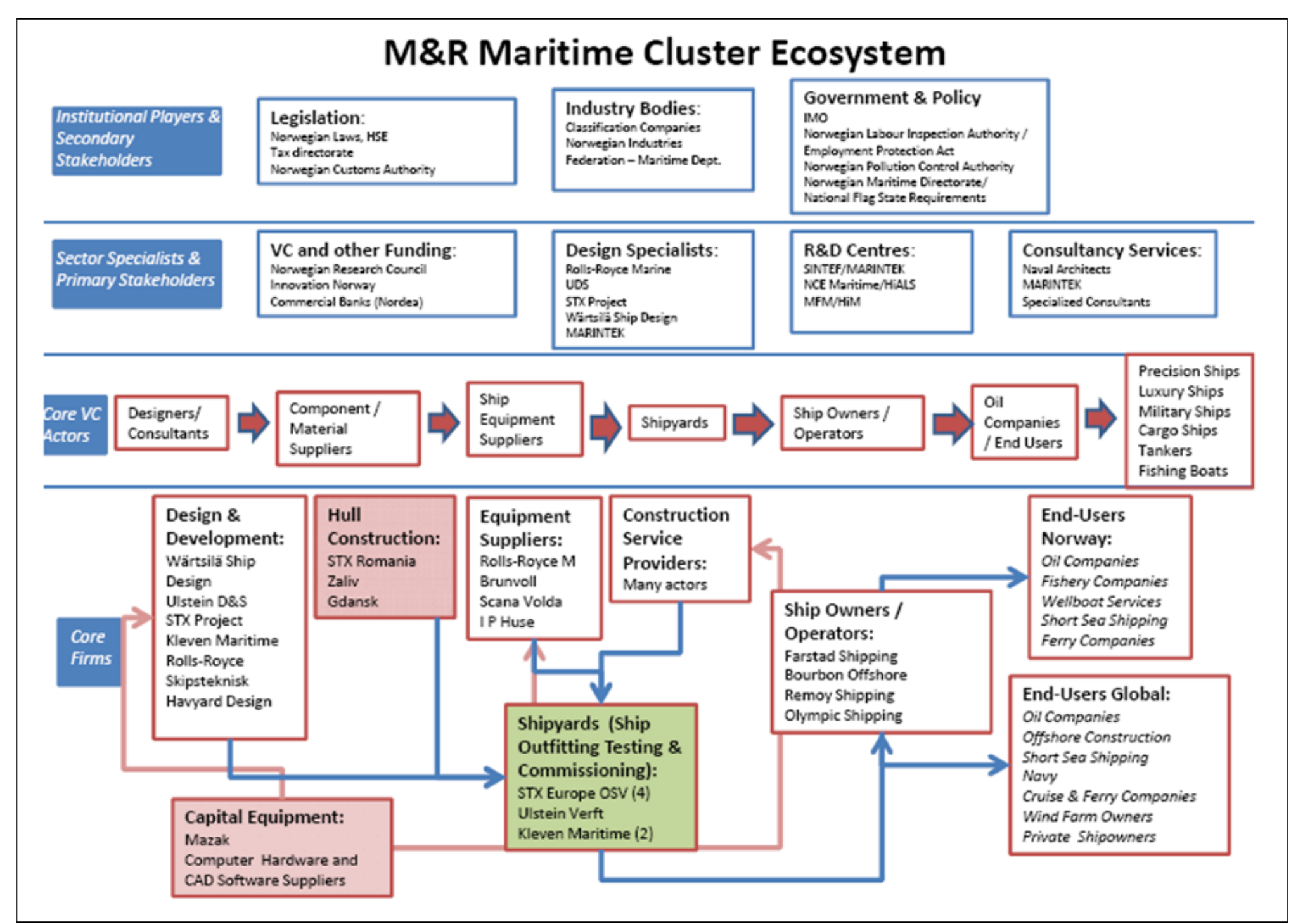




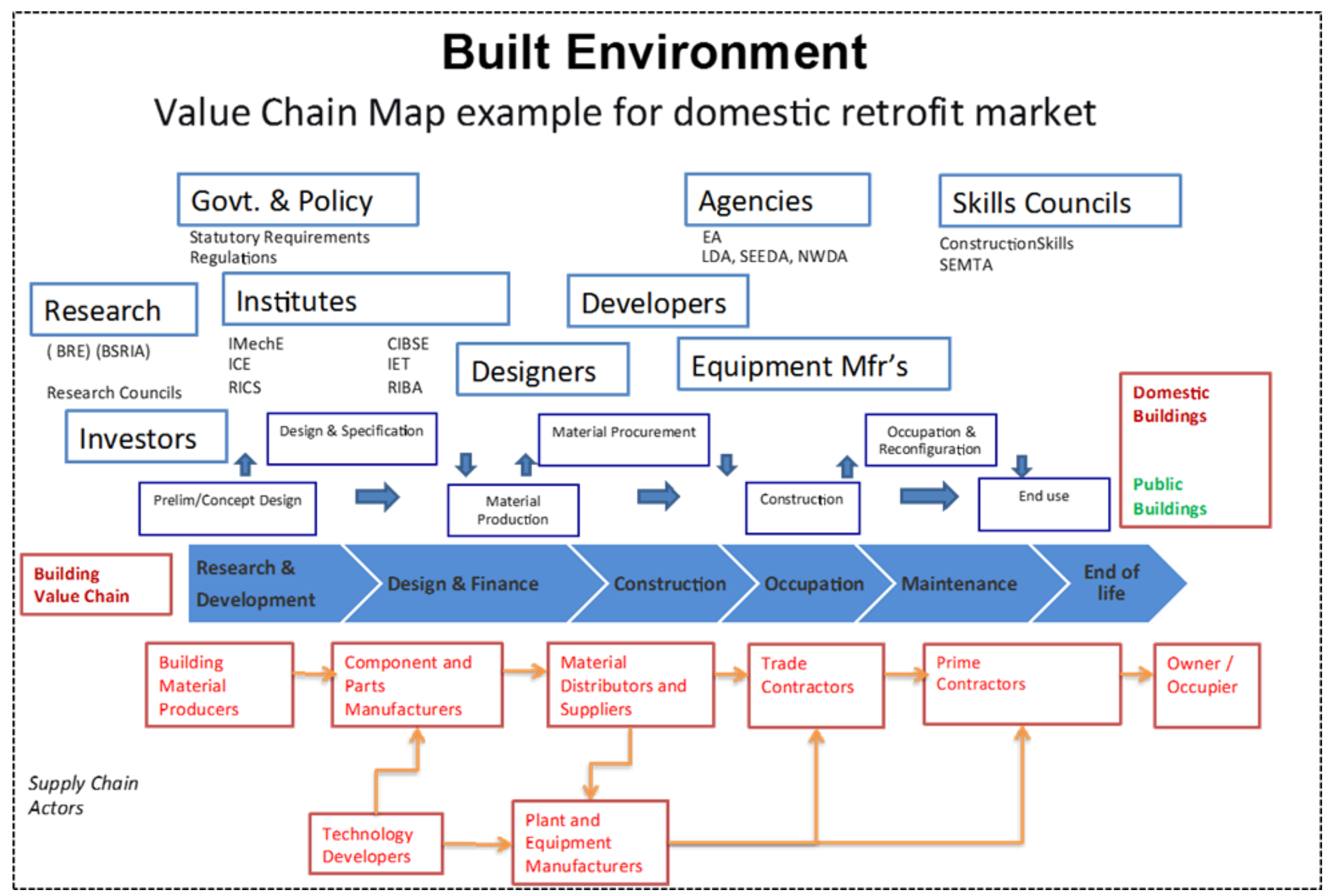




\section{Figure 5. UK Industrial Biotechnology Map}

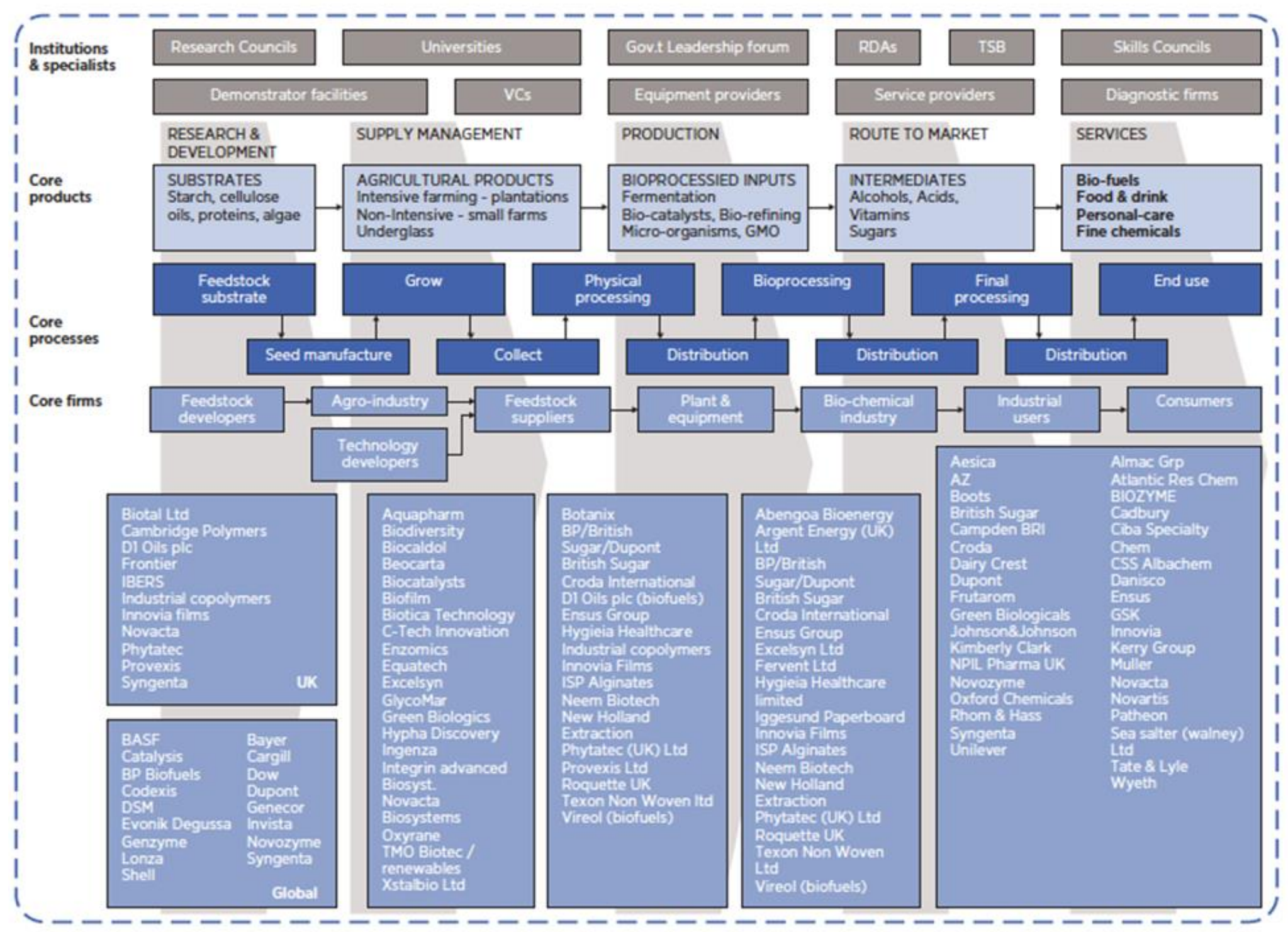


Figure 6. Solar PV sector Map $-1^{\text {st }}$ and $2^{\text {nd }}$ generations

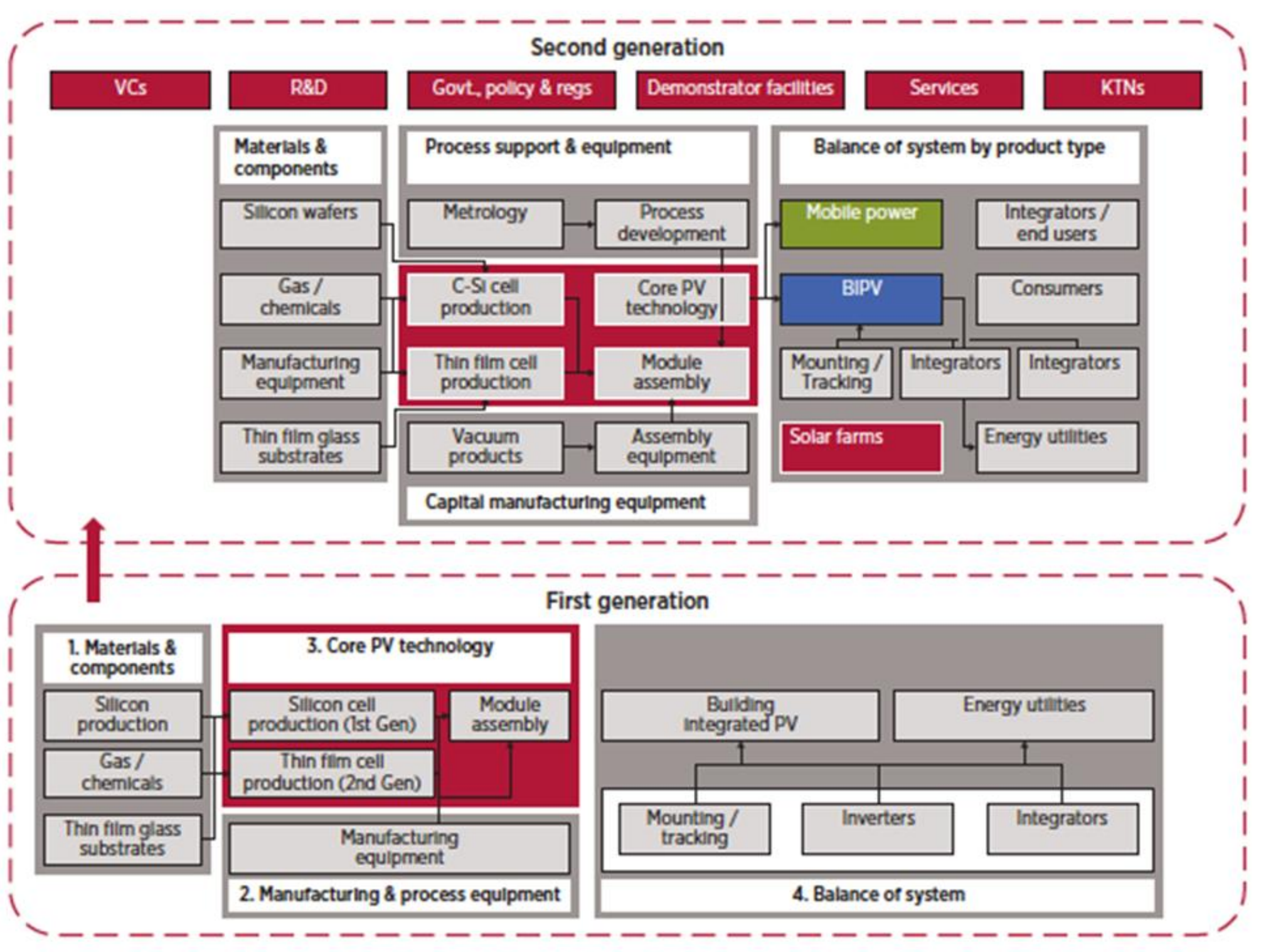


Figure 7. Last Mile Logistics

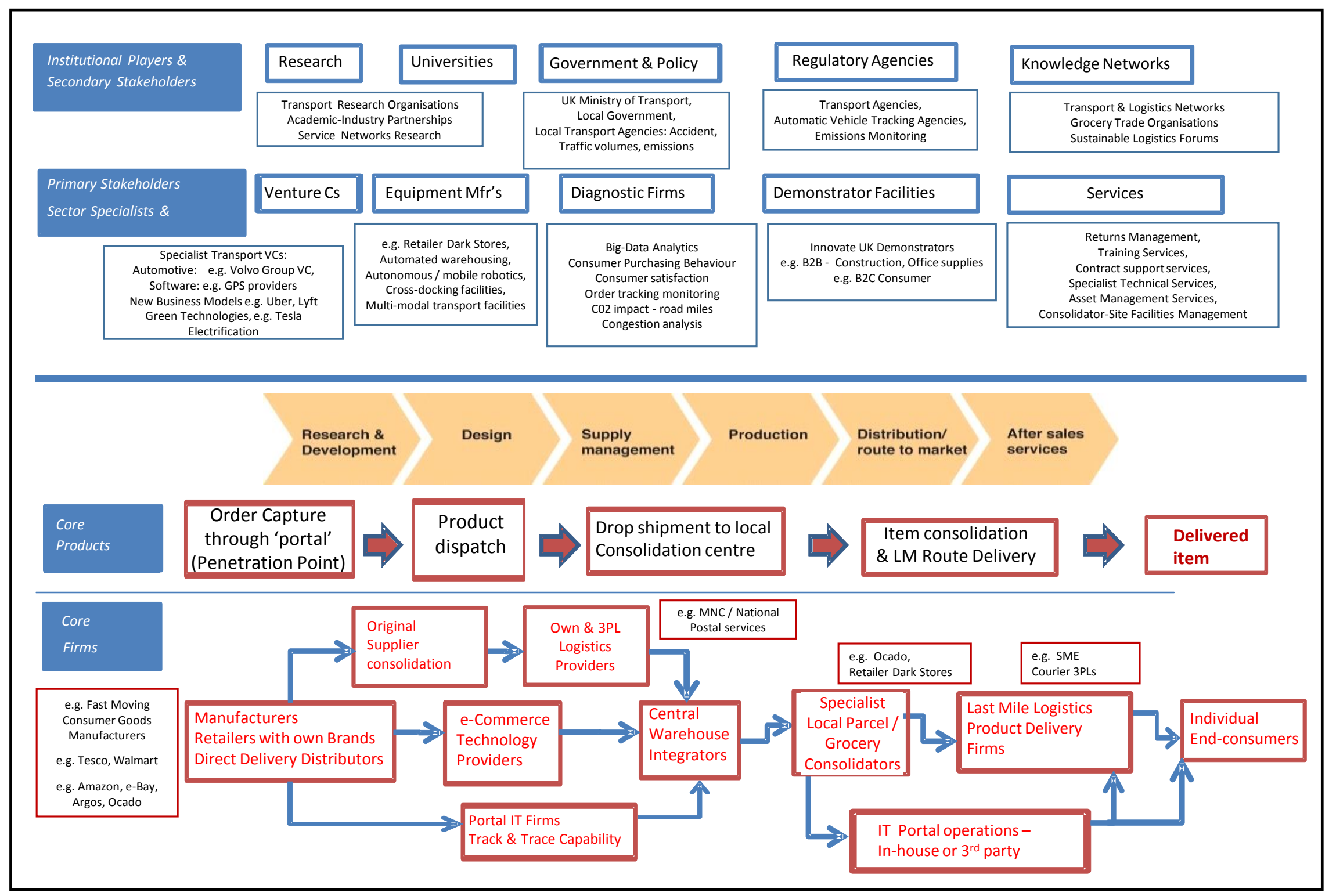




\section{Cross-case analysis - supply network configuration and operations}

\subsection{Supply network configuration}

Table 1 sets out the discriminating features, from a supply network configuration perspective (Srai \& Gregory 2008), for each of the studied industrial systems, setting out which elements of SN configuration support or frustrate El development. Some common features emerge from this crosscase analysis, including;

- the blurring of industry boundaries in almost all cases with 'connections' beyond the traditional 'sector' boundary (but notwithstanding the importance of industry context - see below)

- platform technologies that support multiple product categories 'disconnected' from end-user markets requiring institutional support (to avoid excessive technology firm market failures)

- new SN actors in El that provide 'network integration' and supply/demand balancing capabilities to actively manage supply and demand-side uncertainties

- the 'open' but selective nature of El supply networks with models observed that demonstrate open-upstream models (biotechnology), open-downstream models (service, last mile), as well as single-product category clusters (maritime) with uncertainty/asset pooling coping methodologies selectively deployed to manage both technology and market uncertainty

- EI SN Actor archetypes observed include System integrators, Technology developers, Resource capturers, Asset diversifiers and material/information Consolidators that support particular El evolution paths

- The co-existence of 'product generations' with particular evolution paths for SNs that use either use 1) new assets, distinctly different from those who are diversifying where sunk costs can frustrate or significantly constrain El development, or 2) 'fabless' models that draw manufacturing resources from the wider industrial system.

From a re-distributed manufacturing perspective, cross-case observations of these EI SNs include;

- More fragmented supply networks, with smaller scale actors (across technology - production - distribution) that potentially redistribute resources (both resource used and wealth created)

- Early stage firms that are less resilient and require local/regional institutional support - here geography plays a role in terms of industrial institutions (e.g. maritime cluster) or governments playing early adopter roles

- Regulatory environment initially requires local institutional and regulator support, but rapid subsequent development to serve international markets requires international standards and partnerships

- High levels of uncertainty in EI SNs require new clusters where risk pooling can mitigate against unattractive risk profiles

- More customised/personalised offerings possible as smaller scale operations and IT enable effective capture of niche customer requirements

Collectively these observations suggest the different nature of redistributed manufacturing models, within EISNs, with smaller scale dispersed options that impose less stress on local resources and can have a democratizing effect on the participation in these industrial systems. They however will challenge low-value adding activities, and depending on traditional footprint design models, drive their relocation, both on-shore (where proximity to markets is prioritized) or off-shore (where modular models allow remote sourcing). 
Table 1. Supply network configuration - discriminating features

\begin{tabular}{|c|c|c|c|c|c|c|}
\hline & Defence Aerospace & Maritime & $\begin{array}{c}\text { Built } \\
\text { Environment }\end{array}$ & $\begin{array}{c}\text { Industrial } \\
\text { Biotechnology }\end{array}$ & Photovoltaics & $\begin{array}{l}\text { Last Mile } \\
\text { Logistics }\end{array}$ \\
\hline $\begin{array}{l}\text { Network Structure } \\
\text { (and eco-system) }\end{array}$ & $\begin{array}{c}\text { Through-life contracting } \\
\text { models that are increasingly } \\
\text { industrially dominated; industry } \\
\text { penetrating into all elements of } \\
\text { service delivery }\end{array}$ & $\begin{array}{c}\text { Industry structure moving } \\
\text { from many national } \\
\text { players to International } \\
\text { networks requiring firms } \\
\text { with global scale }\end{array}$ & $\begin{array}{c}\text { New ecosystem lacks } \\
\text { natural leaders and } \\
\text { champions }\end{array}$ & $\begin{array}{c}\text { Upstream players are } \\
\text { small, recently formed } \\
\text { and financially } \\
\text { constrained with high } \\
\text { attrition rates }\end{array}$ & $\begin{array}{l}\text { Series of evolution } \\
\text { paths/models for each } \\
\text { product and technology } \\
\text { generation }\end{array}$ & $\begin{array}{c}\text { New 'route to customer' } \\
\text { models emerging }\end{array}$ \\
\hline $\begin{array}{l}\text { Network Dynamics } \\
\text { (and drivers of } \\
\text { business model) }\end{array}$ & $\begin{array}{l}\text { Failure mode analysis driven } \\
\text { by through-life costs as well } \\
\text { as functional integrity }\end{array}$ & $\begin{array}{c}\text { Radical reconfiguration } \\
\text { paths to meet new market } \\
\text { sectors, new regions }\end{array}$ & $\begin{array}{l}\text { Regulation driving new } \\
\text { business models }\end{array}$ & $\begin{array}{l}\text { End-user market } \\
\text { proliferation likely }\end{array}$ & $\begin{array}{l}\text { Exponential growth in } \\
\text { revenue and actors but } \\
\text { potential remains largely } \\
\text { unexploited }\end{array}$ & $\begin{array}{l}\text { Real-time information } \\
\text { networks are key } \\
\text { enablers }\end{array}$ \\
\hline $\begin{array}{l}\text { Network } \\
\text { relationships, } \\
\text { governance (and } \\
\text { regulatory } \\
\text { environment) }\end{array}$ & $\begin{array}{l}\text { Emerging markets requiring } \\
\text { more dispersed network } \\
\text { capability }\end{array}$ & $\begin{array}{c}\text { Designers talking direct to } \\
\text { end clients }\end{array}$ & $\begin{array}{l}\text { Fragmented network } \\
\text { structure frustrates } \\
\text { rapid evolution }\end{array}$ & \begin{tabular}{|l|} 
Lack of connectedness \\
and visibility between \\
upstream emerging \\
firms and downstream \\
established actors; \\
pairings between SMEs \\
and MNCs emerging
\end{tabular} & $\begin{array}{c}\text { Critical enabling actors for } \\
\text { the models above, which } \\
\text { include technology } \\
\text { developer, V-I resource } \\
\text { acquirers, asset diversifiers }\end{array}$ & $\begin{array}{c}\text { Network Integration } \\
\text { between governance } \\
\text { bodies, industrial actors } \\
\text { and end-users }\end{array}$ \\
\hline $\begin{array}{l}\text { Governance and co- } \\
\text { ordination (and } \\
\text { regulatory } \\
\text { environment) }\end{array}$ & $\begin{array}{c}\text { New Outcome based Service } \\
\text { Models involving multiple } \\
\text { partners }\end{array}$ & $\begin{array}{c}\text { Shift from shipyard control } \\
\text { to design houses and } \\
\text { equipment suppliers } \\
\text { coordinating with end } \\
\text { vessel owner customers }\end{array}$ & $\begin{array}{c}\text { Regulatory uncertainty } \\
\text { and ability to deliver, a } \\
\text { barrier to industry } \\
\text { growth }\end{array}$ & $\begin{array}{l}\text { Regulation can } \\
\text { drive/hinder } \\
\text { development }\end{array}$ & \begin{tabular}{|c|} 
Four supply network \\
evolution models identified - \\
network creation, radical \\
reconfiguration, critical \\
resource acquisition, \\
energy service delivery \\
model
\end{tabular} & $\begin{array}{c}\text { Interface between } \\
\text { regulators, local } \\
\text { government, industry and } \\
\text { end-users, and } \\
\text { academia }\end{array}$ \\
\hline $\begin{array}{l}\text { Changing product } \\
\text { configuration }\end{array}$ & $\begin{array}{l}\text { Unmanned aircraft demanding } \\
\text { real-time information systems, } \\
\text { remote trace and control }\end{array}$ & $\begin{array}{c}\text { bespoke designs focused } \\
\text { on high-end equipment and } \\
\text { vessel specifications }\end{array}$ & $\begin{array}{c}\text { Demand requires step } \\
\text { change in industry scale } \\
\text { but no obvious migration } \\
\text { paths }\end{array}$ & $\begin{array}{c}\text { Great uncertainty on } \\
\text { adoption rates of new } \\
\text { technology }\end{array}$ & $\begin{array}{c}\text { Co-existence of different } \\
\text { technology generations and } \\
\text { product types }\end{array}$ & $\begin{array}{c}\text { B2C e.g. Packages B2B } \\
\text { e.g. Construction, Retail } \\
\text { logistics }\end{array}$ \\
\hline Cross-sector linkages & $\begin{array}{c}\text { Blurring of sector boundaries: } \\
\text { defence, Intelligence and } \\
\text { information driven security } \\
\text { systems (defensive and } \\
\text { offensive) }\end{array}$ & $\begin{array}{c}\text { Blurring of sector } \\
\text { boundaries: maritime, off- } \\
\text { shore wind, energy }\end{array}$ & $\begin{array}{l}\text { Blurring of boundaries: } \\
\text { construction, } \\
\text { environment, energy, } \\
\text { interface between } \\
\text { government, industry } \\
\text { and academia. }\end{array}$ & $\begin{array}{l}\text { IB is a platform } \\
\text { technology }->\text { feeds } \\
\text { multipe sectors rather } \\
\text { than a single sector }\end{array}$ & $\begin{array}{l}\text { Exploitation is limited but } \\
\text { includes solar parks for } \\
\text { additional grid capacity; } \\
\text { industrial scale applications } \\
\text { for selected factory sites; } \\
\text { ad-hoc office and home } \\
\text { applications }\end{array}$ & \begin{tabular}{|c|} 
Blurring of industry \\
boundaries: multi-modal \\
solutions, IT and \\
transport, product and \\
service, retail/industry \\
and logistics.
\end{tabular} \\
\hline
\end{tabular}




\subsection{Supply network operations}

Table 2 sets out for ease of cross-case comparison, the EI SN perspectives for each of the case studies across a common set of operational parameters.

The operational parameters that may determine the distributed nature of EI SNs should consider changes to transport systems impacted by production location, inventory and stock management strategies based on distribution channel developments, and how changes to production processes impact scale and capacity flexibility. El technologies may also have impacts on ability to offer product variety and flexibility.

In terms of transport systems, Table 2 highlights how distributed manufacturing models reduce proximity to market and in the case of product-service systems (Defence Aerospace Servicing, Built Environment) may indeed be co-located with the end customer. Within the EI SN case studies, the need to be more responsive to demand signals require responsive transport systems requiring a variety of distribution models, from direct delivery from centralised warehousing to new near local-touser consolidation centres (as in the case of Last Mile Logistics).

Inventory and strategic stock management strategies within the EI SN cases suggest reduced final product inventory strategies are evolving, partly afforded by smaller economies of scale for production facilities supporting greater product variety, with either make-to-order production or where products are modular in nature centralised inventory, supported by rapid replenishment distribution models.

In terms of production models, more continuous processing operations, either enabled through production technology breakthroughs and/or changes in operating philosophy (e.g. pulse-line maintenance strategies) may support more flow-through SN operations. In discrete assembly industries however (e.g. Maritime) EI SNs in developed economies are more focused on niche high value products that do not fundamentally change $\mathrm{SN}$ structure.

The case studies suggest significantly enhanced product variety and/or flexibility seems to be a key characteristic of EI SNs and may be a key determinant in future industry development. This together with the observed trend in the cases to locate production closer to the end-user suggest $\mathrm{EI}$ SNs will support smaller scale distributed operations where speed, and product/product-service customised solutions are more attractive value propositions, and recent technology developments provide viable options. The progressive digitalisation of El production processes, distribution channels and product tracking, and the capture and replenishment of customer demand suggest that ICT infrastructural developments that underpin these models may be equally relevant to future evolution. Indeed the ability to connect the end-to-end SN - perhaps incorporating product use (e.g. Aerospace Service models, eCommerce Last Mile Logistics) - may further drive EI SN evolution to more local, more niche/customised models. 
Table 2. Supply network operations - discriminating features

\begin{tabular}{|c|c|c|c|c|c|c|}
\hline & Defence Aerospace & Maritime & $\begin{array}{c}\text { Built } \\
\text { Environment }\end{array}$ & $\begin{array}{c}\text { Industrial } \\
\text { Biotechnology }\end{array}$ & Photovoltaics & $\begin{array}{l}\text { Last Mile } \\
\text { Logistics }\end{array}$ \\
\hline $\begin{array}{l}\text { transport system } \\
\text { (mode/multi-modal) }\end{array}$ & $\begin{array}{l}\text { Servicing undertaken at } \\
\text { customer site; advances in } \\
\text { predicative maintainance } \\
\text { enabling spares transport on } \\
\text { demand }\end{array}$ & no significant change & $\begin{array}{c}\text { project based } \\
\text { consolidation centres } \\
\text { located near to build } \\
\text { activity }\end{array}$ & $\begin{array}{l}\text { alternative technology } \\
\text { that favours co-location } \\
\text { (vertical integration) with } \\
\text { downstream operations }\end{array}$ & $\begin{array}{l}\text { supply co-located with } \\
\text { demand reducing } \\
\text { transmission losses }\end{array}$ & $\begin{array}{l}\text { consolidation centres } \\
\text { located near to major } \\
\text { population centres, with } \\
\text { local pick-up and } \\
\text { customer drop-off } \\
\text { models }\end{array}$ \\
\hline $\begin{array}{l}\text { inventory, strategic } \\
\text { stock management }\end{array}$ & $\begin{array}{c}\text { inventory model switched to } \\
\text { flying hours commitments; } \\
\text { service 'capacity' not storable } \\
\text { but transient }\end{array}$ & $\begin{array}{l}\text { non-standard equipment } \\
\text { driving low inventory } \\
\text { models }\end{array}$ & $\begin{array}{l}\text { inventory stored } \\
\text { remotely and at local } \\
\text { consolidation centres; } \\
\text { pull based supply to } \\
\text { final build site }\end{array}$ & \begin{tabular}{|} 
generally like-for-like \\
replacements; some \\
products favour material \\
or process integration \\
with limited inventory
\end{tabular} & $\begin{array}{c}\text { current applications tend to } \\
\text { surplant base-load energy } \\
\text { requirements; surplus return } \\
\text { to grid emerging }\end{array}$ & $\begin{array}{l}\text { multiple consolidation } \\
\text { models, with progessive } \\
\text { decentralisation of } \\
\text { strategic stock closer to } \\
\text { customer }\end{array}$ \\
\hline $\begin{array}{l}\text { production model, } \\
\text { and capacity } \\
\text { management }\end{array}$ & $\begin{array}{c}\text { pulse-line maintainance } \\
\text { strategies allowing semi- } \\
\text { continuous service operations; } \\
\text { capacity planning based on } \\
\text { station unit pulse-time, } \\
\text { capacity flexibility linked to } \\
\text { labour rather than machinery }\end{array}$ & $\begin{array}{c}\text { equipment customised and } \\
\text { made-to-order, designers } \\
\text { enagaging directly with } \\
\text { end customers rather than } \\
\text { shipyards, vessel } \\
\text { production made-to-order } \\
\text { as previous models }\end{array}$ & $\begin{array}{l}\text { refurbish activity is } \\
\text { localised; usually single } \\
\text { site unless regional } \\
\text { programme driven } \\
\text { incentives }\end{array}$ & $\begin{array}{c}\text { current suppliers are } \\
\text { emergent firms with } \\
\text { limited capacity; some } \\
\text { processes favour } \\
\text { upstream materials } \\
\text { integration (renewables) } \\
\text { or downstream } \\
\text { production process } \\
\text { integration }\end{array}$ & $\begin{array}{c}\text { multiple generations of } \\
\text { technology in the market } \\
\text { place; improved efficiencies } \\
\text { of later generations lower } \\
\text { capital costs and enhance } \\
\text { capacity }\end{array}$ & $\begin{array}{l}\text { demand' signals are } \\
\text { digital / e-Commerce } \\
\text { transactions; traditional } \\
\text { retailers omnichannel } \\
\text { strategies require } \\
\text { localisation; new e- } \\
\text { tailers driving single } \\
\text { puchase item to multiple } \\
\text { sales }\end{array}$ \\
\hline $\begin{array}{l}\text { product variety and } \\
\text { flexibility }\end{array}$ & $\begin{array}{l}\text { no change in product variety, } \\
\text { but improved flexibility enabled } \\
\text { by enhanced service reliability }\end{array}$ & $\begin{array}{c}\text { specialisation driving high } \\
\text { value equipment and high- } \\
\text { end vessel focus }\end{array}$ & $\begin{array}{l}\text { standardised materials; } \\
\text { customised upgrades }\end{array}$ & \begin{tabular}{|} 
continuous production \\
processes provide \\
varient flexibility at small \\
scale that might be \\
otherwise uneconomic
\end{tabular} & $\begin{array}{l}\text { increasing product types } \\
\text { but limited flexibility post } \\
\text { installation }\end{array}$ & $\begin{array}{l}\text { Increased SKU variety } \\
\text { and delivery flexibility; } \\
\text { tranditional players using } \\
\text { omnichannel strategies }\end{array}$ \\
\hline
\end{tabular}




\section{Cross-case analysis - importance of type of innovation and 'Context'}

In this section we again consider cross-case characteristics, but briefly highlight the linkages between the type of innovation and contextual factors. Specifically we consider sources of Innovation in terms of process, product, business model innovation and whether this is linked to the exploitation of Firm, Government and Country-specific advantages.

Table 3 summarises the nature of the innovation observed in the emerging industrial system studied and to what extent 'context' specific advantages are exploited to support industrial emergence. To exemplify these complex interactions between the nature of the El innovation, context specific advantages and particular attributes of SN configuration, Figure 8 describes these 'connections' within the maritime cluster case study.

Table 3. Summary of the industry sector mapping studies undertaken - capturing the nature of the industrial innovations observed and the firm, institutional and country advantages being exploited

\begin{tabular}{|c|c|c|c|c|c|c|c|}
\hline \multirow{2}{*}{$\begin{array}{l}\text { Industrial } \\
\text { System }\end{array}$} & \multicolumn{4}{|c|}{ Innovation patterns } & \multicolumn{3}{|c|}{ Advantages } \\
\hline & $\begin{array}{c}\text { Process } \\
\text { innovation }\end{array}$ & $\begin{array}{c}\text { Product } \\
\text { innovation }\end{array}$ & $\begin{array}{l}\text { Business Model } \\
\text { Innovation }\end{array}$ & $\begin{array}{c}\text { New or evolving } \\
\text { industry } \\
\text { structures }\end{array}$ & $\begin{array}{c}\text { Firm } \\
\text { Specific }\end{array}$ & \begin{tabular}{|c|} 
Government \\
or Institutional \\
specific
\end{tabular} & $\begin{array}{l}\text { Country } \\
\text { specific }\end{array}$ \\
\hline Defence Aerospace & & $\nu$ & $\nu$ & $\nu$ & $\nu$ & & $\nu$ \\
\hline Maritime & $\nu$ & $\nu$ & $\nu$ & $\nu$ & $\nu$ & $\nu$ & $\nu$ \\
\hline Built Environment & & $\nu$ & & $\nu$ & & $\nu$ & \\
\hline $\begin{array}{c}\text { Industrial } \\
\text { Biotechnology }\end{array}$ & $\mathcal{V}$ & $\mathcal{V}$ & $\nu$ & $\nu$ & $\nu$ & & \\
\hline Photovoltaics & $\nu$ & & $\nu$ & & $\mathcal{V}$ & & $\nu$ \\
\hline Last Mile Logistics & & & $\nu$ & $\nu$ & & $\nu$ & \\
\hline
\end{tabular}

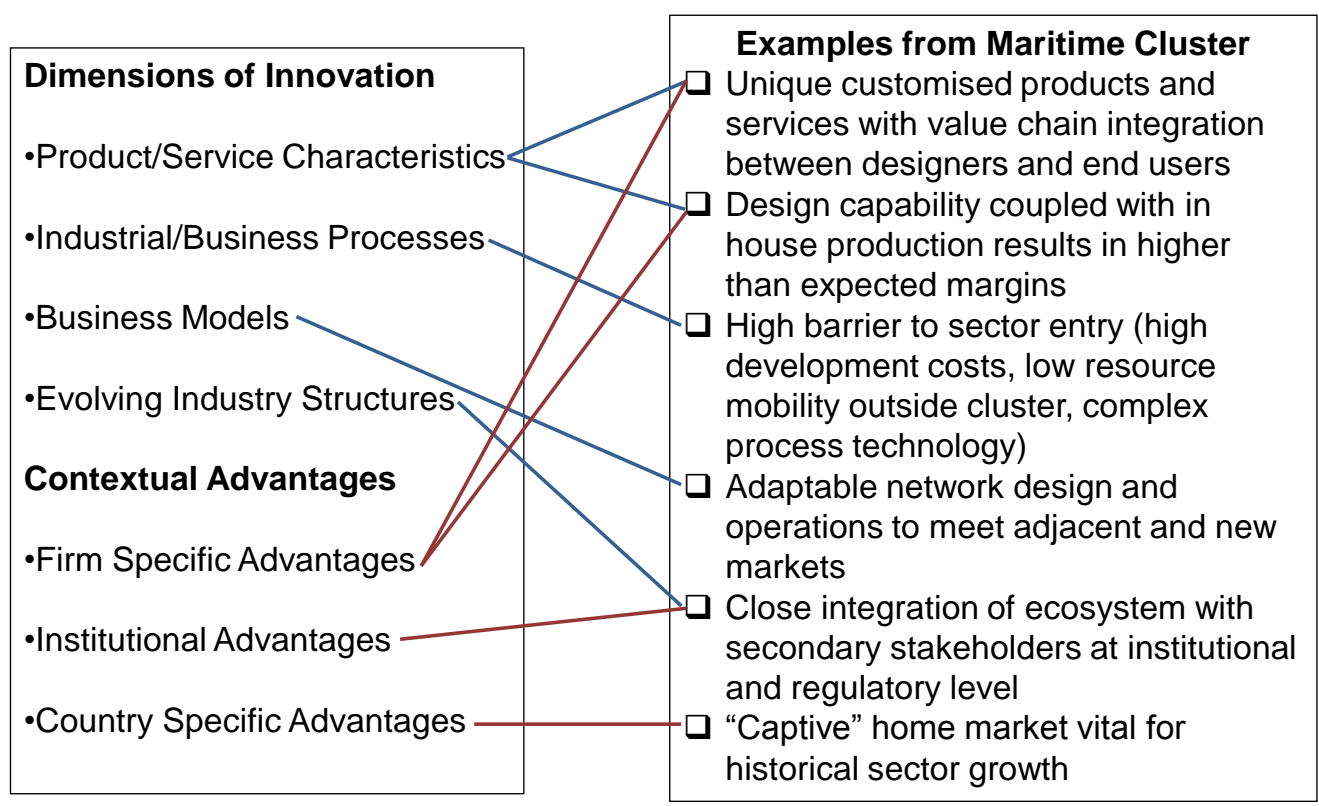

Figure 8. Linkages between Nature of Innovation and Industry Context (maritime cluster example) 


\section{Discussion - conceptualising linkages between technology and industry SN transformation}

The methodologies utilised in this research provide a basis for understanding current and future SN configurations, and the emerging industrial system in which it takes place, including the interconnections between actors that need to take place to enable industry evolution.

The research has described a well-understood linkage between technology platforms and final product innovations. However, limited attention is paid to the industrial system that 'connects' technology developments to final products; the application of the mapping approach and subsequent analysis provides insights into EI SN configurational (Table 1) and operational (Table 2) implications.

Conceptualising how industry transformation is connected to technology and product enhancements is presented in Figure 7. The schematic demonstrates the current state industrial value chain/system, and how it reconfigures to provide a linkage between technologies and technology options (i.e. V1 -> V2) to product iterations (i.e. P1->P2). It runs orthogonal to the standard technology or product roadmaps and identifies the industrial challenges in reconfiguring the industrial chain for new and emerging industries.

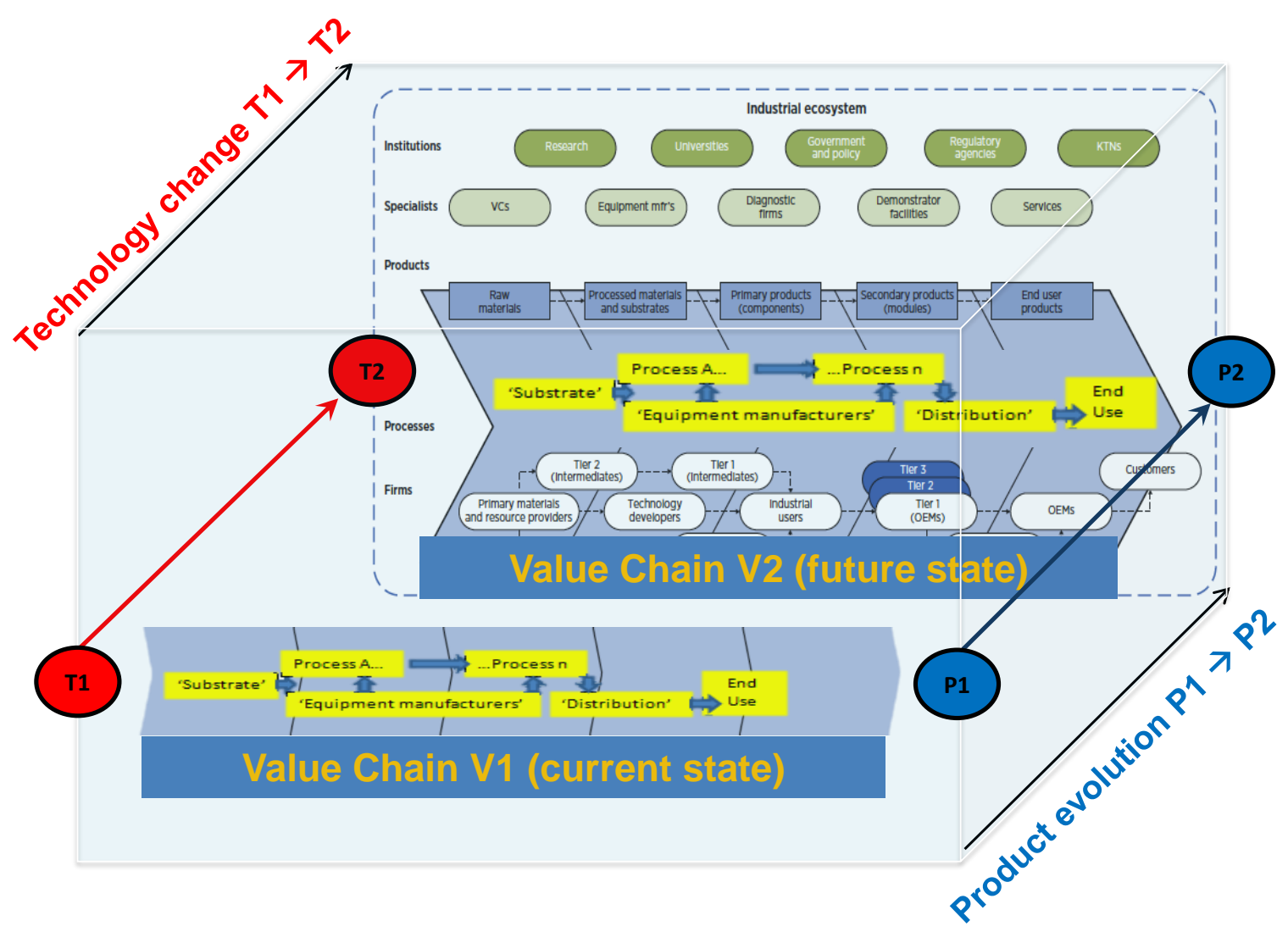

Figure 9. Reconfiguring EI SNs

The conceptual framework in Figure 9 can be used to demonstrate linkages between supply network 'states' or reconfiguration paths; linking industry structure (back-plate), and how the manufacturing value chain evolves from the initial technology development (T1), and the formation of a supply or value network (V1), to a SN reconfiguration process that supports new products and services (technology transition $\mathrm{T} 1->\mathrm{T} 2$, industrial value chain transformation $\mathrm{V} 1->\mathrm{V} 2$, resulting in new products P1 -> P2). 


\section{Conclusions and Future Work}

An industrial system mapping methodology that has previously been developed (Srai and Christodoulou 2014, Srai, 2016), is utilised to explore emerging industry supply networks. The methodology enabled the capture in a consistent manner, the mapping of emerging industrial systems and provide a basis for cross-case analysis. This exploratory research examined six industrial systems using this methodology in order to better understand generic supply network dimensions of industrial emergence and their enabling network configurations. These industrial systems were selected on the basis of representing alternative and novel evolution paths that might provide an initial understanding of the key characteristics of emerging industry supply networks.

Cross-case analysis suggests several generic aspects to EI SNs, including the blurring of industry boundaries, and the critical requirement to manage uncertainty in selective elements of the value chain. Alternative forms of EI SNs have been observed, in some product areas often co-existing within the same product sector. In the case of platform technologies that support multiple product categories, these are often 'disconnected' from their end-user markets. From a SN structure perspective the importance of particular SN actors in El that provide 'network integration' and supply/demand balancing capabilities to actively manage supply and demand-side uncertainties are observed and include System integrators, Technology developers, Resource capturers, Asset diversifiers and material/information Consolidators each supporting particular El evolution paths.

From a redistributed manufacturing $\mathrm{SN}$ operations perspective, smaller scale dispersed options potentially impose less stress on local resources with positive effects on industrial sustainability. They can also have a democratizing effect on the participation within these industrial systems at a socio-economic level. These redistributed manufacturing systems can drive more adaptive and responsive SNs which can support increased product variety but with lower inventory models, made possible by production being closer to demand and enhanced production flexibility. Similarly, as seen by the examples on Last Mile logistics, new eCommerce models, involving the digitalisation of supply chains can support rapid replenishment and decoupled distribution channels, with drop-points located closer to end-users.

This work describes approaches and frameworks for assessing the ways in which supply networks can influence and shape emerging industries. Future research opportunities include the further development of the industry evolution (cube) model (Figure 9), by integrating supply network and value chain configuration concepts, with product technology road-mapping frameworks, and/or scenario planning tools. The current study is limited by a small sample size of sector studies, and further industrial system case studies can be usefully used to test and validate the initial conclusions.

\section{Acknowledgements}

The authors would like to acknowledge the industrial collaborators who provided access to their organisations, supply network, industrial and institutional partners.

\section{References}

Aized, T and Srai, J.S., (2013). Hierarchical modelling of Last Mile Logistics Distribution System. International Journal of Advanced Manufacturing Technology, 70 (5-8) 1053-1061

Awa H.O. (2010) "Democratizing the new product development process", International Business Research 3(2), 49,

Brennan, L, Bakir, C, (2016). “Emerging country multinationals”, Publ. Routledge ISBN: 978-1-13892018-7 (hbk), ISBN: 978-1-315-68728-5 (ebk)

Capra, F., (2002), 'The hidden connections - A Science for Sustainable Living', Publ. Harper

Choi, T.Y. and Krause, D.R. (2006), "The supply base and its complexity: implications for transaction costs, risks, responsiveness, and innovation", Journal of Operations Management, 24/25, 637-652. 
Dicken, P. (2003), Global Shift: Reshaping the Global Economic Map in the 21st Century, 4th edition 2003; London: Sage Publications Ltd.

Funk JL. (2012). The unrecognized connection between vertical disintegration and entrepreneurial opportunities. Long Range Planning 45:41-59.

Gregory, M.J. (2005) "Viewpoint-Making the most of manufacturing-globally", IEE Review, 51(7), 5656

Guvåg, B. Srai, J.S., Karolis, D., Oterhals, O (2013) “A High Value Production Network - At Work”, $17^{\text {th }}$ Annual Cambridge International Manufacturing Symposium, $19-20^{\text {th }}$ September.

Harrington, T.S., Srai, J.S. (2012) 'Defining product-service network configurations and location roles: a current and future state analysis framework for international engineering operations', Int. J. Product Development, Vol. 17, Nos. 3/4, pp. 228-253. DOI: 10.1504/IJPD.2012.052103

Harrington T.S., and Srai J.S., (2016), 'Understanding stages of supply network emergence in technology commercialisation', International Journal of Manufacturing Technology and Management

Harrington, T.S., Srai, J.S., Kumar, M., Wohlrab, J. (2016), 'Identifying design criteria for urban system 'last-mile' solutions - a multi-stakeholder perspective', Production Planning and Control, DOI:10.1080/09537287.2016.1147099

lakovaki, A (2011), 'Service Supply Chain Integration in Multi-Organisational Networks'. PhD Thesis, University of Cambridge

Jacobides MG, Winter SG. (2005). The co-evolution of capabilities and transaction costs: explaining the institutional structure of production. Strategic Management Journal 26: 395-413.

Jacobides MG. (2005). Industry change through vertical disintegration: How and why markets emerged in mortgage banking. Academy of Management Journal 48(3): 465-498.

Jacobides MG. (2008). How capability differences, transaction costs and learning curves interact to shape vertical scope. Organization Science 19(2): 306-326.

Kamath, N.B. and Roy, R. (2007), "Capacity augmentation of a supply chain for a short lifecycle product: a system dynamics framework", European Journal of Operational Research, 179, 2, 334351.

Kirkwood, D.A. and Srai, J.S. (2009) "Charting Industry Emergence from a Supply Network Perspective: the evolution of the photovoltaic industry" ICMR'09, Warwick

MacCarthy, B., Blome, C., Olhager, J., Srai, J.S., Zhao, X., (2016) 'Supply Chain Evolution - Theory, Concepts, Science', International Journal of Operations and Production Management, DOI 10.1108/IJOPM-02-2016-0080

Moore, J.F. (1993) Predators and Prey: A New Ecology of Competition", Harvard Business Review May

Nair, A., Boulton, W.R., (2008) 'Innovation- oriented operations strategy typology and stage- based model', International Journal of Operations and Production Management, Vol. 28, No. 8, pp. 748771.

Porter, M.E. (1980) Competitive Strategy, The Free Press, McMillan.

Ramamurti, R. and Jitendra V. Singh, eds. (2010) Emerging Multinationals from Emerging Markets.

Cambridge, UK and New York: Cambridge University Press. ISBN: 9780521160186 
Rezk, R., Srai, J.S., Williamson P., (2016), 'The impact of product attributes and emerging technologies on firms' international configuration', Journal of International Business Studies, online March 2016, doi:10.1057/jibs.2016.9, June/July 47 (5), pp. 610-618

Rugman, Alan M. (1986), "New Theories of the Multinational Enterprise: an assessment of Internationalisation Theory", Bulletin of Economic Research, 38, 102

Simchi-Levi, D. and Fine, C.H. (2010) "Your next supply chain", MIT Sloan Management Review, 51, 2, 17-25.

Shin, M., Mun, J., Lee, K., Jung, M (2009) r-FrMS: a relation-driven fractal organisation for distributed manufacturing systems, IJPR, 47, 7, 1791-1814. DOI:10.1080/00207540802036240

Srai J.S., (2007). 'Global Solutions; Supply Chains - Emerging Models. Manufacturing Engineer', The Institution of Engineering and Technology. Oct-Nov 2007, 86 (5), 32-35. 5.

Srai, J.S., (2011). Supply network integration in multi-organisational network systems, special issue of the International Journal of Manufacturing Research, on Systems for Extended Enterprises, 6 (2): $122-133$

Srai, J.S. (2016) "Mapping Industrial Systems - a supply network perspective on enabling technologies, processes and actors" International Journal of Manufacturing Technology Management

Srai J.S., Kumar M., Graham G., Phillips W., Tooze J., Tiwari M.K., Ford S., Beecher P., Raj B., Gregory M.J., Tiwari M.K., Ravi B., Neely A., Shankar R., Charnley F., and Tiwari A., (2016), 'Distributed Manufacturing: scope, challenges and opportunities', International Journal of Production Research doi.org/10.1080/00207543.2016.1192302

Srai, J.S., and Christodoulou, P., (2014). "Capturing Value from Global Networks; Strategic approaches to configuring international production, supply and service operations", University of Cambridge IfM Publication ISBN: 978-1-902546-30-8.

Srai, J.S. and Gregory, M. (2008) "A Supply network configuration perspective on international supply chain development", International Journal of Operations and Production Management 28, 5, 386411

Srai, J.S., Harrington, T.S., Alinaghian, L.S., Phillips, M.A. (2015) 'Evaluating the potential for the continuous processing of pharmaceutical products - a supply network perspective', Chem. Eng. Process. In press, available online: 8th August. DOI: 10.1016/j.cep.2015.07.018

Srai J.S., Kumar M., Graham G., Phillips W., Tooze J., Tiwari M.K., Ford S., Beecher P., Raj B., Gregory M.J., Tiwari M.K., Ravi B., Neely A., Shankar R., Charnley F., and Tiwari A., (2016), 'Distributed Manufacturing: scope, challenges and opportunities', International Journal of Production Research, doi.org/10.1080/00207543.2016.1192302

Technology Strategy Board Strategic Report, (2010) "Emerging Technologies and Industries: Strategy 2010-2013" www.innovateuk.org, 5th January 2011

Utterback, J.M. (1994) "Mastering the dynamics of innovation: how companies can seize opportunities in the face of technological change

Williamson, P. and Zeng, M. (2009) "Value-for-money strategies for recessionary times." Harvard Business Review, 87(3): 66-74 


\section{Appendix 1}

Table 4. Data Collection - Respondents, Timelines, Product Categories covered, and data-triangulation

\begin{tabular}{|c|c|c|c|c|c|c|}
\hline & Defense Aerospace & Maritime & Built Environment & $\begin{array}{c}\text { Industrial } \\
\text { Biotechnology }\end{array}$ & Photovoltaics & Last Mile Logistics \\
\hline Respondents & $\begin{array}{l}\text { over } 75 \text { multi-stakeholder semi- } \\
\text { structured interviews along the } \\
\text { end-to-end service chain with } \\
\text { Integrated Project Teams. } \\
\text { Includes suppliers, system } \\
\text { integrators, critical equipment } \\
\text { providers, Squadron leaders, } \\
\text { Strike Command end customer }\end{array}$ & $\begin{array}{l}\text { primary respondents include } \\
\text { sector organisations; major } \\
\text { OEMs, shipyard owners, } \\
\text { specialist equipment providers; } \\
\text { extensive sector data collated } \\
\text { annually by local sector team }\end{array}$ & \begin{tabular}{|} 
National Built Environment \\
Leadership team, Major design \\
organisation, Construction \\
Consolidation Centre \\
organisation, Logistics Providers, \\
Local Government planning \\
agencies
\end{tabular} & $\begin{array}{c}\text { Sub-category supply chain } \\
\text { mapping with OEM Directors from } \\
\text { each of the product categories } \\
\text { (see below) }\end{array}$ & $\begin{array}{l}\text { multi-stakeholder supply chain } \\
\text { actor interviews with each of the } \\
\text { three PV product generations }\end{array}$ & $\begin{array}{l}\text { LM Logistics cluster organisation } \\
\text { comprising multiple stakeholders } \\
- \\
\text { Co-lead on two embedded LM } \\
\text { application projects including } \\
\text { concept development, design, } \\
\text { prototype implementation }\end{array}$ \\
\hline Timeline & \begin{tabular}{|c|} 
Tornado ATTAC programme \\
team interviewed across \\
multiple time periods - re- \\
assembly of original design \\
team, first application test site, \\
extensive case study of multi- \\
stakeholders on air force (RAF) \\
application site \\
\end{tabular} & $\begin{array}{c}\text { quantitative annual data spanning } \\
\text { top } 150 \text { firms spanning last } 15 \\
\text { years }\end{array}$ & $\begin{array}{c}\text { Primary data from building design, } \\
\text { architect firms, construction } \\
\text { logistics, construction } \\
\text { warehousing and consolidation }\end{array}$ & $\begin{array}{c}4 \text { product categories mapped at } \\
\text { different stages on sub-sector } \\
\text { evolution. (No primary longitudinal } \\
\text { data mapped) }\end{array}$ & $\begin{array}{l}\text { Industry evolution studies } \\
\text { spanned the period } 2007-2010\end{array}$ & $\begin{array}{c}\text { Business-to-Business (B2B) and } \\
\text { Business to Consumer (B2C) } \\
\text { longitudinal studies spanning } \\
2009-2014\end{array}$ \\
\hline $\begin{array}{l}\text { Product Category } \\
\text { mapping }\end{array}$ & $\begin{array}{c}\text { Tornado ATTAC programme, } \\
\text { Hercules HIOS, Harrier HISS } \\
\text { programme, Typhoon } \\
\text { Eurofighter }\end{array}$ & $\begin{array}{c}\text { High end niche shipping vessels - } \\
\text { specific OEM product } \\
\text { organisations, specific equipment } \\
\text { providers }\end{array}$ & \begin{tabular}{|c|} 
high-level sector level analysis \\
supported by specific \\
Construction Consolidation Centre \\
Reviews on major public projects
\end{tabular} & $\begin{array}{l}\text { Bio-Fuels, Fast Moving Consumer } \\
\text { Goods Food \& Drink, Personal } \\
\text { Care, Fine Chemicals }\end{array}$ & $\begin{array}{l}\text { 1st Generation PV, } \\
\text { 2nd Generation PV, } \\
\text { 3rd Generation PV }\end{array}$ & $\begin{array}{c}\text { B2B Parcel project mapping } \\
2009 \text {-2014 } \\
- \\
\text { B2C Construction project } \\
\text { mapping 2009-2012 }\end{array}$ \\
\hline $\begin{array}{c}\text { Peer-Review Publication } \\
\text { of Individual Sector } \\
\text { maps }\end{array}$ & $\begin{array}{c}\text { lakovaki, A (2011), } \\
\text { Srai, J.S., (2011). } \\
\text { Harrington, T.S., Srai, J.S., } \\
\text { (2012). }\end{array}$ & $\begin{array}{l}\text { Guvåg, B. Srai, J.S., Karolis, D., } \\
\text { Oterhals, O (2013) }\end{array}$ & - & $\begin{array}{l}\text { Srai, J.S. (2010), } \\
\text { Srai, J.S., (2016) }\end{array}$ & $\begin{array}{l}\text { Kirkwood, D.A. and Srai, J.S. } \\
\text { (2009), Srai, J.S. (2016) }\end{array}$ & $\begin{array}{l}\text { Aized, T and Srai, J.S., (2013), } \\
\text { Harrington, T.S., Srai, J.S., } \\
\text { Kumar, M., Wohlrab, J. (2016) }\end{array}$ \\
\hline Data triangulation & $\begin{array}{l}\text { National Audit Office Reports on } \\
\text { Tornado, Typhoon, } \\
\text { Participation in Major Research } \\
\text { programme (S4T) on Service } \\
\text { (through-life contracting) for } \\
\text { Transformation and Multi- } \\
\text { Organisational Networks (MON) }\end{array}$ & $\begin{array}{l}\text { Comparative mapping studies in } \\
\text { other Norwegian maritime } \\
\text { clusters }\end{array}$ & \begin{tabular}{|} 
Extensive secondary data from \\
Built Environment specialist \\
organisations \\
Secondary data on application \\
models used in Heathrow \\
Terminal 5, London Olympics Built \\
Environment projects
\end{tabular} & $\begin{array}{l}\text { Sector report published with } \\
\text { secondary references included } \\
\text { (Srai 2010) }\end{array}$ & $\begin{array}{l}\text { Sector reports - included in } \\
\text { paper references above }\end{array}$ & $\begin{array}{l}\text { Sector reports - included in } \\
\text { paper references above }\end{array}$ \\
\hline
\end{tabular}

